Haya: The Saudi Journal of Life Sciences

Abbreviated Key Title: Haya Saudi J Life Sci ISSN 2415-623X (Print) |ISSN 2415-6221 (Online) Scholars Middle East Publishers, Dubai, United Arab Emirates Journal homepage: https://saudijournals.com/sjls

Original Research Article

\title{
Proximate, Vitamins, Minerals Compositions Together with Mineral Ratios and Mineral Safety Index of Kilishi (Beef Jerky Meat)
}

Emmanuel Ilesanmi Adeyeye $^{1^{*}}$, Adeolu Jonathan Adesina ${ }^{1}$, Ademola Abdul Olaleye ${ }^{2}$, Sulaimon Adeoye Olagboye ${ }^{1}$, Mercy Ayomadewa Olatunya ${ }^{1}$

${ }^{1}$ Department of Chemistry (Analytical Chemistry Unit), Faculty of Science, Ekiti State University, PMB 5363, Ado - Ekiti, Nigeria

${ }^{2}$ Department of Chemistry, Federal University Dutse, PMB 7156, Jigawa State, Nigeria

DOI: $10.36348 /$ sjls.2020.v05i05.005

| Received: 04.03.2020 | Accepted: 16.03.2020 | Published: 30.05.2020

*Corresponding author: Emmanuel Ilesanmi Adeyeye

Abstract

Kilishi is a great spicy beef jerky from Nigeria. Dry kilishi was analysed for its content of chemical components: proximate, vitamins, minerals using standard methods. From the minerals were calculated the mineral ratios and the mineral safety index (MSI). Highest concentrations of proximate contents came from crude protein $(64.4 \mathrm{~g} / 100 \mathrm{~g})$ and crude fat was $14.2 \mathrm{~g} / 100 \mathrm{~g}$. Proportion of total energy due to protein was $1,095 \mathrm{~kJ} / 100 \mathrm{~g}(66.0 \%)$ or $258 \mathrm{kcal} / 100 \mathrm{~g}(65.3 \%)$ whereas in carbohydrate we had values of $39.1 \mathrm{~kJ} / 100 \mathrm{~g}(2.36 \%)$ or $9.20 \mathrm{kcal} / 100 \mathrm{~g}(2.33 \%)$. Utilization of $60 \%$ of proportion of total energy due to protein percent ranged between 39.2 - 39.6. Minerals of high concentration in the sample were (mg/100g): K, 985 (44.3\%); P, 781 (35.1\%); Na, 320 (14.4\%); reasonable contents were observed in Fe, Zn, $\mathrm{Ca}, \mathrm{Mg}$. Among all the minerals ratios calculated, only the value for $\mathrm{Na} / \mathrm{Mg}$ (3.91) was very close to reference balance ideal (4.00) and within the acceptable ideal range (2 to 6). The MSI values showed that only $\mathrm{Zn}$ was higher than the recommended MSI showing that $\mathrm{Zn}$ might be deleterious in kilishi consumption. The two most concentrated vitamins were water soluble vitamins with values of (mg/100g): vitamin $\mathrm{C}, 6.53(38.4 \%)$; $\mathrm{B}_{3}, 5.98(35.2 \%)$ and followed by two other fat soluble vitamins: vitamin A, 1.94 (11.4\%) and vitamin E, 1.38 (8.10\%). These results revealed that kilishi could be regarded as a protein-filled snack that still retains its nutritional value despite being dried.

Keywords: Kilishi meat, chemical composition, healthy snack.

Copyright @ 2020: This is an open-access article distributed under the terms of the Creative Commons Attribution license which permits unrestricted use, distribution, and reproduction in any medium for non-commercial use (NonCommercial, or CC-BY-NC) provided the original author and source are credited.

\section{INTRODUCTION}

Kilishi (kilichi) is a spicy beef jerky that is popular in the northern part of Nigeria. It is one of the Nigerian snacks. It is often mistaken for suya because they have similar ingridients but preparation and texture are different. Jerky is lean trimmed meat that has been cut into strips and dried (dehydrated) to prevent spoilage. Usually, the drying includes the addition of salt to prevent bacterial growth before the meat has finished dehydrating process (Jerky - Wikipedia). The quality of kilishi is further improved as follows. A paste made from peanuts, called $l a b u$, is diluted with enough water, spices, salt, ground onions, and sometimes sweeteners such as honey, to add sweetness. A more natural way to add sweetness is by adding date palm. The dried "sheet" of meat are then immersed one after the other in the labu paste to coat them, before being left to dry for hours before roasting to taste [1].
Meat ranks among one of the most significant, nutritious and favoured item available to the people, it aids in fulfilling most of their body requirements. It is an important constituent of a well-balanced diet. It is a good source of proteins, low source of carbohydrates, moderate source of fat, good source of minerals and vitamins [2]. Other ingredients or treatments to improve the quality of kilishi are: use of suya spice (suya pepper); cloves of garlic; one teaspoon of cloves (kanafuru); piece of ginger; stock cube; dry cayenne pepper seeds; the meat used for kilishi should be free from fat and should be gotten from the reddish part of the beef. Each of these items give kilishi special characteristics such as aroma, etc [3].

The information above gave some insight on the preparation, food characteristics and ingredients that make up kilishi. There is paucity of information on the chemical composition of kilishi. The major concern of this work is therefore to find out if an improvement occurs when beef is treated into kilishi snack meat. To 
address this concern, the following were analyzed for in kilishi: proximate constituent, mineral constituent and vitamin constituent. Discussion was based on these compositions in relation to literature information as well as health implications of the consumption of kilishi as a beef product.

\section{MATERIALS AND METHODS \\ Collection of Samples}

Samples of packaged kilishi were obtained from NAO Supermarket in Ado - Ekiti, Ekiti State, Nigeria. The kilishi samples were prepared for sale by Golden Datol Ent., Akure, Ondo State, Nigeria. The kilishi was labelled as containing beef, onion, garlic, salt, honey, ginger, maggi, groundnut and pepper. A typical kilishi sample is shown in Figure-1.

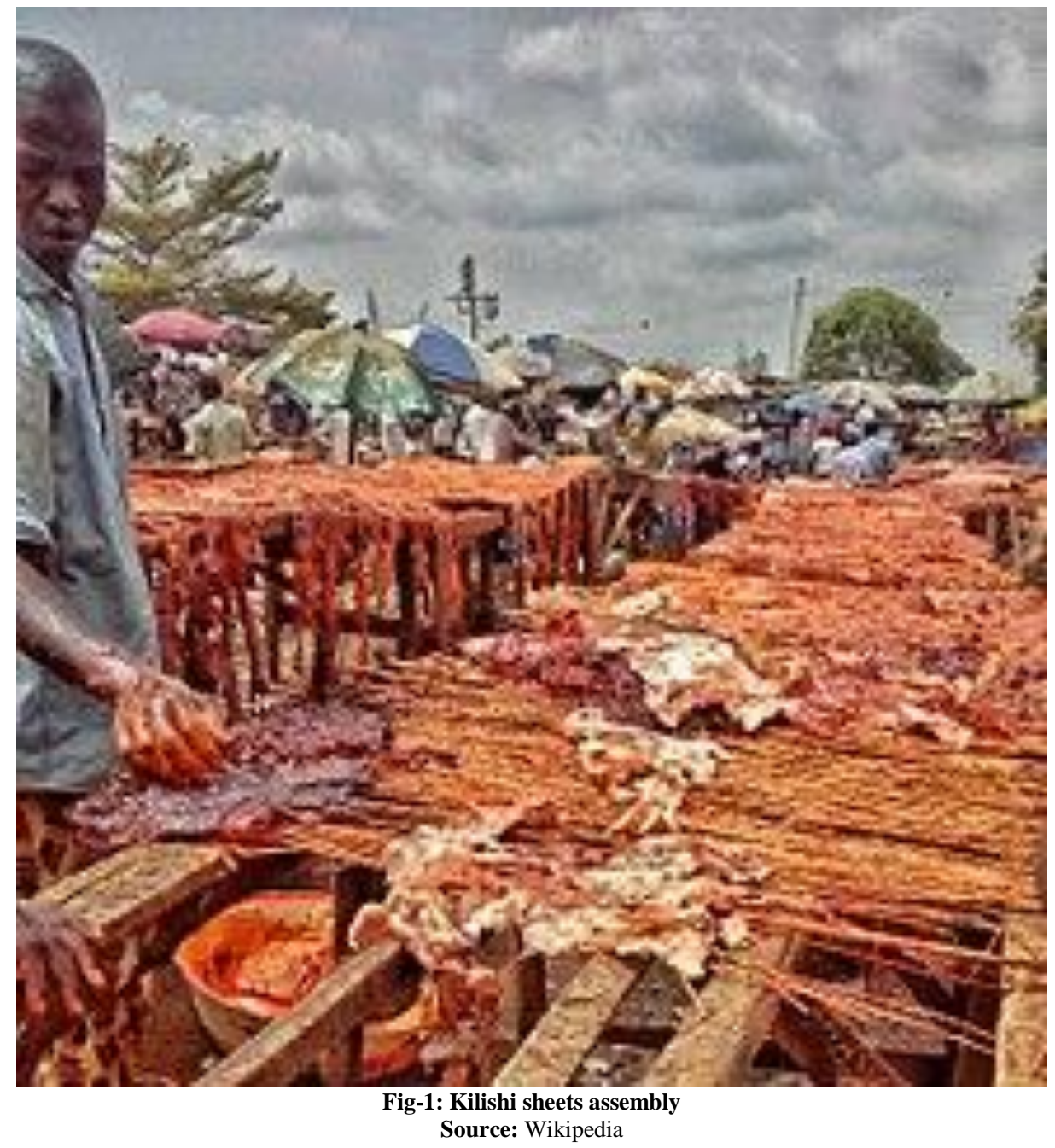

\section{Sample Treatment}

The kilishi pack were further dried at $50^{\circ} \mathrm{C}$ in the oven, allowed to cool, blended and packaged in plastic containers and kept in the refrigerator pending analysis.

\section{Sample Analyses \\ Proximate Determination}

Micro-Kjedahl method [4] was followed to determine the crude protein. The crude fat was extracted with a chloroform/methanol $(2: 1 \mathrm{v} / \mathrm{v})$ mixture using Soxhlet extraction apparatus [5] method while carbohydrate was determined by difference. The calorific value in kilojoule $(\mathrm{kJ})$ and kilocalorie (kcal) were calculated by multiplying the crude fat, protein and carbohydrate by Atwater factors of (kJ/kcal) 37/9,
$17 / 4$ and 17/4 respectively. All determinations were in duplicate.

\section{Mineral Element Determination}

The minerals were analyzed from the solution obtained by initially dry ashing the samples at $550^{\circ} \mathrm{C}$. Filtered solutions were used to determine $\mathrm{Na}, \mathrm{K}, \mathrm{Ca}$, $\mathrm{Mg}, \mathrm{Zn}, \mathrm{Fe}, \mathrm{Mn}, \mathrm{Cu}, \mathrm{Pb}, \mathrm{Co}, \mathrm{Cd}, \mathrm{Ni}$ and Se by means of atomic absorption spectrophotometer (Buck Scientific Model- 200A/210, Norwalk, Connecticut 06855). Phosphorus was determined colorimetrically by Spectronic 20 (Gallenkamp, UK) using the phosphovanado molybdate method [5]. All chemicals used were of British Drug House (BDH, London, UK) analytical grade. Earlier, the detection limits for the metals in aqueous solution had been determined using 
the methods of Varian Techtron [6]. The optimal analytical range was 0.1-0.5 absorbance units with coefficients of variation from $0.9 \%$ to $2.21 \%$. From the mineral elements determined, further calculations were made.

\section{Mineral Ratios}

Ratios of $\mathrm{Ca} / \mathrm{Mg}, \mathrm{Na} / \mathrm{K}, \mathrm{Ca} / \mathrm{K}, \mathrm{Na} / \mathrm{Mg}, \mathrm{Zn} / \mathrm{Cu}$, $\mathrm{Ca} / \mathrm{P}, \mathrm{Fe} / \mathrm{Cu}, \mathrm{Ca} / \mathrm{Pb}, \mathrm{Fe} / \mathrm{Pb}, \mathrm{Zn} / \mathrm{Cd}, \mathrm{Fe} / \mathrm{Co}, \mathrm{K} / \mathrm{Co}$ and $[\mathrm{K} /(\mathrm{Ca}+\mathrm{Mg})]$ were all calculated [7-9].

\section{Mineral Safety Index (MSI)}

The mineral safety index (MSI) [7] of Na, P, $\mathrm{Ca}, \mathrm{Fe}, \mathrm{Se}, \mathrm{Zn}$ and $\mathrm{Cu}$ were calculated using the formula:

Calculated MSI = MSI/RAI x Research data result

Where,

MSI = mineral safety index Table (standard)

$\mathrm{RAI}=$ recommended adult intake.

\section{Simultaneous Analysis of Fat and Water Soluble Vitamins}

The samples were brought out of the less than $4^{\circ} \mathrm{C}$ compartment in the laboratory and placed on the bench to allow acclimatizing to the laboratory conditions.

\section{Extraction of Water-soluble Vitamins}

The sample was ground with the aid of the laboratory mortar and pestle. Accurately weighed value of $0.100 \mathrm{~g}$ of ground sample was put into $100 \mathrm{ml}$ volumetric flasks and $80 \mathrm{ml}$ of deionized water added. After $15 \mathrm{~min}$ of ultrasonic extraction, the water was added to the volumetric flask mark.

\section{Extraction of Fat-soluble Vitamins}

A weighed value of $0.125 \mathrm{~g}$ of ground sample was added into $10 \mathrm{ml}$ volumetric flasks and $8 \mathrm{ml}$ of $\mathrm{CH}_{3} \mathrm{OH}-\mathrm{CH}_{2} \mathrm{Cl}_{2}$ was added to the volumetric flask mark. This prepared solution was stored in the dark; and diluted if need be. Prior to injection, the solutions were filtered through a $0.2 \mu \mathrm{m}$ filter (Millex-GN).

\section{Optimized Chromatography Conditions}

Water and fat soluble vitamins were separated simultaneously under the following optimized chromatography conditions combined with valve switching, double injection, envelope-injection and wavelength switching.

\section{Column}

Acclaim PA, $3 \mu \mathrm{m}, 120 \mathrm{~A}, 3.0 \times 150 \mathrm{~mm}$ for fat soluble. Acclaim C18, $3 \mu \mathrm{m}, 120 \mathrm{~A}, 3.0$ x $150 \mathrm{~mm}$ for water soluble.
Column Temperature: $25^{0} \mathrm{C}$

Mobile Phase

For Water-soluble Vitamin Determination

(A) $25 \mathrm{~mm}$ phosphate buffer (dissolved $\sim 3.4 \mathrm{~g}$

$\mathrm{KH}_{2} \mathrm{PO}_{4}$ in $100 \mathrm{ml}$ water, and adjust $\mathrm{pH}$ to 3.6 with $\mathrm{H}_{3} \mathrm{PO}_{4}$ ).

(B) $\mathrm{CH}_{3} \mathrm{CN}$ Mobile Phase A (7:3, v/v).

\section{For Fat-soluble Vitamin Determination}

(A) $\mathrm{CH}_{3} \mathrm{OH}-\mathrm{CH}_{3} \mathrm{CN}(8: 2$, v/v).

(B) Methyl tert-butyl ether (MTBE)

Injection volume: 10 $\mu 1$ (Dionex, Technical Note 89) (www.dionex.com). All determinations were on dry weight basis.

\section{PubChem CID For Mineral Elements}

Mineral elements studied in this report were: Copper/Cu (PubChem CID: 23978); Iron/Fe (PubChem CID: 23925); Zinc/Zn (PubChem CID: 23994); Magnesium/Mg (PubChem CID: 5462224); Calcium/Ca (PubChem CID: 5460341); Cobalt/Co (PubChem CID: 104730); Manganese/Mn (PubChem CID:23930); Sodium/Na (PubChem CID: 5360545); Potassium/K (PubChem CID: 5462222); Nickel/Ni (PubChem CID: 935); Phosphorous/P (PubChem CID: 5462309); Selenium/Se (PubChem CID: 6326970); Lead/Pb (PubChem CID: 5352425); Cadmium/Cd (PubChem CID: 23973).

\section{PubChem CID For Mineral Vitamins}

Retinol (PubChem CID: 445354); Cholecalciferol (PubChem CID: 5280795); Cyanocobalamin (PubChem CID: 5311498); alphaTocopherol (PubChem CID: 14985); 3-Hyroxy-vitamin K (phylloquinone) (PubChem CID: 5280540); Niacin (PubChem CID: 938); Riboflavin (PubChem CID: 493570); Pyridoxamine (PubChem CID: 1054); Thiamine (PubChem CID: 1130); Folic acid (PubChem CID: 6037); Pantothenic acid (PubChem CID: 6613); Ascorbic acid (PubChem CID: 54670067).

PubChem is a database of chemical molecules and their activities against biological assays. The system is maintained by the National Centre for Biotechnology Information (NCBI), a component of the National Library of Medicine, which is part of the United States National Institute of Health (NIH). Hence we can talk of PubChem Compound ID (CID) [10].

\section{RESULTS AND DISCUSSION}

In Table-1 we have the proximate composition as well as the energy contribution to the total metabolizable energy from carbohydrate, crude fat and crude protein. The ash and moisture levels were moderately concentrated whereas both crude fibre and carbohydrate contents were low. From the metabolizable energy results, carbohydrate contributed the lowest value of $39.1 \mathrm{~kJ} / 100 \mathrm{~g}$ kilishi $(2.36 \%)$ or 9.20 $\mathrm{kcal} / 100 \mathrm{~g}$ kilishi $(2.33 \%)$; crude fat was second with 
energy contribution value of $525 \mathrm{~kJ} / 100 \mathrm{~g}$ (31.7\%) or $128 \mathrm{kcal} / 100 \mathrm{~g}(32.4 \%)$ whereas crude protein contributed the highest energy value of $1095 \mathrm{~kJ} / 100 \mathrm{~g}$ $(66.0 \%)$ or $258 \mathrm{kcal} / 100 \mathrm{~g}(65.3 \%)$ giving an overall total energy of $1659 \mathrm{~kJ} / 100 \mathrm{~g}$ or $395 \mathrm{kcal} / 100 \mathrm{~g}$ dry kilishi. Assuming 60\% utilization of the proportion of total energy due to protein percent (UEDP\%), we have values of 39.6 (under kJ energy) and 39.2 (under kcal energy). Removal of elements of water content in the sample gave solid content value of $88.8 \mathrm{~g} / 100 \mathrm{~g}$ whereas removal of both moisture content and ash content gave the value of $81.3 \mathrm{~g} / 100 \mathrm{~g}$ as the organic matter of kilishi. To convert the crude fat to fatty acid and other lipids, the crude fat was multiplied by a value of 0.916 [11], i.e. $14.2 \times 0.916=13.0 \mathrm{~g} / 100 \mathrm{~g}$ meaning that about 1.2 $\mathrm{g} / 100 \mathrm{~g}$ of the crude fat would be due to other forms of lipid. This fatty acid value gave metabolizable energy values of $481 \mathrm{~kJ} / 100 \mathrm{~g}$ or $117 \mathrm{kcal} / 100 \mathrm{~g}$ kilishi.

The keeping quality of any biological sample will depend partly on its moisture content. The moisture content of the kilishi sample was $11.2 \mathrm{~g} / 100 \mathrm{~g}$ (Table-1). Low moisture will always discourage microbial growth. It is known for kilishi that after roasting, the final moisture content ranged between $10-12 \%$ which decreases during storage at room temperature to $7.0 \%$. When packaged in hermetically sealed low density plastic pack of $0.038 \mathrm{~mm}$ thickness, kilishi remains appreciably stable at room temperature for a period of about one year. Both the crude fibre $(0.40 \mathrm{~g} / 100 \mathrm{~g})$ and carbohydrate $(2.30 \mathrm{~g} / 100 \mathrm{~g})$ were of low values. Whilst the low crude fibre would have led to high digestibility of kilishi, the low carbohydrate could have led to the correspondingly high crude protein content.

The crude protein of $64.4 \mathrm{~g} / 100 \mathrm{~g}$ was high. This value was almost at par with the values of $65.4-$ $68.5 \mathrm{~g} / 100 \mathrm{~g}$ as observed in Acanthurus monroviae and Lutjanus goreensis fishes [12]. A source of protein is an essential element of a healthy diet, allowing both growth and maintenance. There has been debates and published works on protein intake and health. Issues that arise from the potential for protein intakes are predicated on protein intakes to be in excess of the recommended intake [13]. These potential deleterious issues were based mostly on renal function, bone health, kidney stones, cardiovascular disease and cancer. For bone health, protein as part of a wellbalanced diet may be beneficial for bone, possibly at dietary levels in excess of the recommended intake; in order to minimize the risk of kidney stones in patients who are at risk, the protein safe level of $0.83 \mathrm{~g} / \mathrm{kg}$ per day is recommended but not in excessive amounts (i.e. less than $1.4 \mathrm{~g} / \mathrm{kg}$ per day, preferably from vegetable sources; inverse relationships between protein intake and blood pressure have been reported [14, 15]; for cancer, it has been reported that high dietary protein results in better survival in women with breast cancer [16]. From our results, a kilishi consumption of 64.4 $\mathrm{g} / 100 \mathrm{~g}$ per day would yield greater than $58.1 \mathrm{~kg}$ per day for a $70 \mathrm{~kg}$ adult by an excess of $6.3 \mathrm{~g} / 100 \mathrm{~g}$ or $9.78 \%$.

The total ash of $7.70 \mathrm{~g} / 100 \mathrm{~g}$ was at moderate concentration level. The ash gives an estimate of the likely mineral composition of any sample. The ash content would likely lead to moderate levels of the mineral elements.

The crude fat content was also at a moderate level. The crude fat level of $14.2 \mathrm{~g} / 100 \mathrm{~g}$ was close to the values of $11.8-12.5 \mathrm{~g} / 100 \mathrm{~g}$ in the innards of male and female Neopetrolisthes maculatus [17]. The calculated total fatty acid value was $13.0 \mathrm{~g} / 100 \mathrm{~g}$ whereas the remaining lipid content composition was $1.20 \mathrm{~g} / 100 \mathrm{~g}$. This $13.0 \mathrm{~g} / 100 \mathrm{~g}$ FA had energy equivalent value of $481 \mathrm{~kJ} / 100 \mathrm{~g}$ or $117 \mathrm{kcal} / 100 \mathrm{~g}$ whereas energy from the total lipid was $525 \mathrm{~kJ} / 100 \mathrm{~g}$ or $128 \mathrm{kcal} / 100 \mathrm{~g}$ kilishi. The crude fat of $14.2 \mathrm{~g} / 100 \mathrm{~g}$ was an indication that the kilishi samples would be good for people wanting to avoid animal protein with high level of fat.

The metabolizable energy as contributed from protein, carbohydrate and total lipid to the total metabolizable energy can be observed also in Table 1. For energy values in $\mathrm{kJ}$, the contributions were: carbohydrate [39.1 (percentage level of 2.36)] < crude fat $[525$ (percentage $=31.7)]<$ crude protein $[1095$ (percentage $=66.0$ )] with corresponding kcal values of $9.20(2.33 \%)<128(32.4 \%)<258(65.3 \%)$. The following literature values would show that kilishi was a moderate source of fat: sheep lean meat (2.06 $\mathrm{MJ} / 100 \mathrm{~g})$, lean pork (2.29 MJ/100g) [18]; lower than in cereals having energy range of $1.3-1.6 \mathrm{MJ} / 100 \mathrm{~g}$ [19]; eight organs of guinea-fowl had metabolizable energy levels of $1.61-1.71 \mathrm{MJ} / 100 \mathrm{~g}$ [20]. Protein contributed the highest energy value of $1.10 \mathrm{MJ} / 100 \mathrm{~g}$ and $66.0 \%$ contribution was close to the energy values of $944-$ $966 \mathrm{~kJ} / 100 \mathrm{~g}$ or $64.7-65.2 \%$ from the proteins of male and female $N$. maculatus respectively [17].

In terms of energy need, the daily energy requirement for an adult is between $2500-3000 \mathrm{kcal}$ which depends on ones physiological state whilst it is $740 \mathrm{kcal}$ in infants [21]. This translated to mean that an adult would have to consume between $634-760 \mathrm{~g}$ to make up the energy range of 2,500 - $3000 \mathrm{kcal}$ whilst infants would require $188 \mathrm{~g}$ of kilishi to satisfy their energy needs. These values were lower than $733-880 \mathrm{~g}$ (adults) and $220 \mathrm{~g}$ (infants) in A. monroviae; $735-882 \mathrm{~g}$ (adults) and 221g (infants) in L. goreensis [12]; in Callinectes latimanus, it was $915 \mathrm{~g}$ (adults minimum) and 271 (infants) [22]; 786 - 944g (muscle) and 761 913 (skin) of turkey to meet adult requirements but $233 \mathrm{~g}$ (muscle) and 325g (skin) in infants [23]. However the values of $634-760 \mathrm{~g}$ were highly comparable to the values of $649-733$ (adult man) and $188 \mathrm{~g}$ was also highly comparable to $192 \mathrm{~g}$ (infants) [20]. The utilizable energy due to protein (UEDP\%) was high at 39.2-39.6 
(assuming $60 \%$ of protein energy utilization). This is much higher than the recommended safe level of $8 \%$ for adult man that requires $55 \mathrm{~g}$ protein per day with $60 \%$ utilization. Comparable literature values to these UEDP\% were 56.4 (turkey muscle), 40.0 (turkey skin) [23]; 38.8 - 39.1 in male and female N. maculatus innards [17]. The UEDP\% of 39.2-39.6 would be far more than enough to prevent energy malnutrition in children and adults that depend solely on kilishi as the main protein source. The sample could also be used to fortify or supplement protein deficient cereal products. The recommended PEF\% from food sources is $30 \%$ of the total energy requirement [24] or the value of $35 \%$ [25] for total fat intake. The present PEF\% value of 31.7-32.4 fell within the two recommended levels as shown above. It meant the consumption of kilishi would be very useful to people wishing to adopt the guidelines for a healthy diet.

As changes occur in dietary, nutritional status and age of an animal, appreciable shifts occur in the tissue compartments, water and protein levels [26]. For the efficient utilization and conservation of food within the human body, water is indispensable [27], it is because the water content of the body changes with the type of diet [28]. This important connection of water with other food substances is the fact that the biochemical basis for the relationship arises from the fact that the water deficit created by protein metabolism is about seven times that for equivalent calories of carbohydrates or fat. Therefore, in young children an increase in calories from carbohydrate causes hydration; whereas an increase in calories from proteins causes dehydration [29]. The increased output of ketones and acids that accompanies a shift to high-fat diets is associated with increased water loss that can be offset by increase in carbohydrate intake. Protein quality as well influences the degree of tissue hydration. Albanese [30] had estimated grammes of water needed for complete metabolism of 100 calories of some food substances. Food materials (protein, starch and fat) all have preformed water of 0.00 in each case; water gained by oxidation: 10.3 (protein), 13.9 (starch) and 11.9 (fat); lost in dissipating heat: 60.0 for each of the food material; water lost in excreting end products (1 calorie of protein requires $3.0 \mathrm{ml}$ of water for the excretion of the urea and sulphate formed from it, $1 \mathrm{~g}$ of ash requires $65 \mathrm{ml}$ of water for its excretion): 300 (protein), both 0.00 in starch and fat; deficit: 350 (protein), 46 (starch) and 48 (fat). From Table 1, 258 $\mathrm{kcal} / 100 \mathrm{~g}$ energy from the kilishi protein would require $774 \mathrm{ml}$ of water for complete metabolism. Hence, water deficit $=350 / 100 \times 258=903 \mathrm{ml}$; hence $903-774=$ $129 \mathrm{ml}$. (This is because 100 calories have water deficit of $350 \mathrm{ml}$.) This means that a lot of water (just below one litre: $903 \mathrm{ml}<1000 \mathrm{ml}$ by $129 \mathrm{ml}$ ) would always be needed for consumption in taking the diet containing kilishi.

Table-1: Proximate composition of kilishi (beef jerky meat) and energy contribution from carbohydrate, crude protein and crude fat

\begin{tabular}{|l|lll|}
\hline Proximate & Energy contribution & & \\
\hline Parameter & Value $\mathbf{( g / 1 0 0 g})$ & $\mathbf{k J} / \mathbf{1 0 0 g}$ (\% value) & kcal/100g (\% value) \\
\hline Total ash & 7.50 & - & - \\
\hline Moisture & 11.2 & - & - \\
\hline Crude fibre & 0.40 & - & - \\
\hline Carbohydrate & 2.30 & $39.1(2.36)$ & $9.20(2.33)$ \\
\hline Crude protein & 64.4 & $1,095(66.0)$ & $258(65.3)$ \\
\hline Crude fat & 14.2 & $525(31.7)$ & $128(32.4)$ \\
\hline Total energy & - & 1,659 & 395 \\
\hline UEDP $(\%)$ & - & 39.6 & 39.2 \\
\hline
\end{tabular}

UEDP = utilization of $60 \%$ of proportion of total energy due to protein percent; - = not applicable.

In Table-2, we have the mineral values and their ratios. Minerals of major significant values were (mg/100g): Fe, Zn, Ca, Mg, K, P and Na. Total minerals observed in the kilishi was $2225 \mathrm{mg} / 100 \mathrm{~g}$. For major minerals observed in the sample, their percentage (\%) values were $\mathrm{Fe}$ (3.88 e-1), Zn (8.23 e-1), Ca (1.33), $\mathrm{Mg}$ (3.67), K (44.3), P (35.1) and Na (14.4). Minerals in traces in the sample were: $\mathrm{Cu}, \mathrm{Mn}, \mathrm{Pb}, \mathrm{Se}, \mathrm{Cd}, \mathrm{Ni}$ and Co whose percentage values ranged from 8.99 e-6 to 8.23 e-1. Mineral ratios of nutritional significance were $\mathrm{Ca} / \mathrm{P}, \mathrm{Na} / \mathrm{K}, \mathrm{Ca} / \mathrm{K}, \mathrm{Zn} / \mathrm{Cu}, \mathrm{Na} / \mathrm{Mg}, \mathrm{Fe} / \mathrm{Cu}$ and $[\mathrm{K} /(\mathrm{Ca}+$ $\mathrm{Mg})$ ]. All these significant ratios have their values in the results being less or greater than the ideal as well as not falling within the acceptable ideal range. Toxic mineral ratios in kilishi were: $\mathrm{Fe} / \mathrm{Pb}, \mathrm{Ca} / \mathrm{Pb}, \mathrm{Zn} / \mathrm{Cd}$ whereas other ratios were $\mathrm{Fe} / \mathrm{Co}$ and $\mathrm{K} / \mathrm{Co}$.
The various mineral contents, their percentage values and their ratios (where appropriate) were depicted in Table 2. Minerals of high content values were: $\mathrm{mg} / 100 \mathrm{~g}$ (percentage value): $\mathrm{Mg}, 81.6$ (3.67), K, 985 (44.3), P, 781 (35.1) and Na, 320 (14.4) whereas moderate levels were $\mathrm{Zn}, 18.3$ (8.23 e-1), Fe, 8.62 (3.88 e-1) and $\mathrm{Ca}, 29.6$ (1.33). Others, such as $\mathrm{Cu}, \mathrm{Mn}, \mathrm{Pb}$, $\mathrm{Se}, \mathrm{Cd}, \mathrm{Ni}$ and $\mathrm{Co}$ were in traces with percentage value range of 8.99 e- 6 to 1.44 e-2. These minerals: $\mathrm{Fe}, \mathrm{Cu}$, $\mathrm{Mn}, \mathrm{Se}, \mathrm{Ni}$ and Co should be sourced from other animal protein sources when kilishi serves as the main source of animal protein. The presence of $\mathrm{Pb}, 0.0009 \mathrm{mg} / 100 \mathrm{~g}$ (4.05 e-5\%) and Cd, $0.0002 \mathrm{mg} / 100 \mathrm{~g}$ (8.99 e-6\%) showed that both minerals were at ultra-trace levels and their presence in kilishi could be an evidence of onset of pollution. Calcium is an important mineral in human 
nutrition being important for bone density. Calcium salts provide rigidity to the skeleton and calcium ion play many roles in most metabolic processes [31]. Nearly $99.0 \%$ of the calcium in the human body is found in the bones [32]. The recommended daily intake of calcium is about $400-500 \mathrm{mg} /$ day for adults. Compared with other minerals, calcium absorbance to the body is relatively inefficient; in general, only about $25.0 \%-30.0 \%$ of dietary calcium is effectively absorbed [31]. When the amount of $\mathrm{Ca}$ is adequate in the diet, $\mathrm{Fe}$ is utilized to better advantage; this is said to be an instance of sparing action [33]. Both $\mathrm{Fe}$ and $\mathrm{Ca}$ were low in the kilishi.

Phosphorous plays an important role in the bones as well as in the cellular membranes as a component of the phospholipids building the membrane lipid bilayer. In addition, it is also a component of many intracellular compounds as nucleic acids, nucleoproteins and organic phosphates such as creatine phosphate and adenosine triphosphate. The total content of phosphorous in the human body is about $700 \mathrm{~g}$ of which $80.0 \%$ are found in the bones, $10.9 \%$ in viscera and $9.00 \%$ in the skeleton muscle tissue [34, 32]. Deficiency of phosphorous in the body leads to muscle disorder, metabolic acidosis, encephalopathy and alteration in bone mineralization as well as in cardiac, respiratory, neurological and metabolic disorders [32]. In many publications, $P$ is suggested to be better sources from the following: between 204 and 230 $\mathrm{mg} / 100 \mathrm{~g}$ in fish, mollusks, crustaceans, when compared to $176 \mathrm{mg} / 100 \mathrm{~g}$ in terrestrial meat [35]. Phosphorous in kilishi was much higher than the literature values.

Table-2: Mineral composition and mineral ratios of kilishi (beef jerky meat)

\begin{tabular}{|c|c|c|c|c|c|c|}
\hline \multirow{2}{*}{$\begin{array}{l}\text { Mineral } \\
\text { Parameter }\end{array}$} & \multirow[b]{2}{*}{$\begin{array}{l}\text { Value } \\
(\mathrm{mg} / 100 \mathrm{~g})\end{array}$} & \multicolumn{5}{|c|}{ Mineral ratio } \\
\hline & & $\begin{array}{l}\text { Percentage } \\
\text { value }\end{array}$ & $\begin{array}{l}\text { Mineral } \\
\text { ratio }\end{array}$ & $\begin{array}{l}\text { (Reference } \\
\text { balance ideal) }\end{array}$ & $\begin{array}{l}\text { Acceptable } \\
\text { ideal range }\end{array}$ & $\begin{array}{l}\text { Calculated } \\
\text { mineral ratio }\end{array}$ \\
\hline $\mathrm{Fe}$ & 8.62 & $3.88 \mathrm{e}-1$ & $\mathrm{Ca} / \mathrm{Mg}$ & 7.00 & 3 to 11 & $3.62 \mathrm{e}-1$ \\
\hline $\mathrm{Cu}$ & 0.32 & $1.44 \mathrm{e}-2$ & $\mathrm{Ca} / \mathrm{K}$ & 4.20 & 2.2 to 6.2 & $3.00 \mathrm{e}-2$ \\
\hline $\mathrm{Mn}$ & 0.0009 & $4.05 \mathrm{e}-5$ & $\mathrm{Zn} / \mathrm{Cu}$ & 8.00 & 4 to 12 & 58.0 \\
\hline $\mathrm{Pb}$ & 0.0009 & $4.05 \mathrm{e}-5$ & $\mathrm{Ca} / \mathrm{P}$ & 2.60 & 1.5 to 3.6 & $3.78 \mathrm{e}-2$ \\
\hline $\mathrm{Zn}$ & 18.3 & $8.23 \mathrm{e}-1$ & $\mathrm{Fe} / \mathrm{Cu}$ & 0.90 & 0.2 to 1.6 & 27.3 \\
\hline $\mathrm{Ca}$ & 29.6 & 1.33 & $\mathrm{Ca} / \mathrm{Pb}$ & 84.0 & 126 to 168 & 31,456 \\
\hline $\mathrm{Mg}$ & 81.6 & 3.67 & $\mathrm{Fe} / \mathrm{Pb}$ & 4.40 & 6.60 to 8.80 & 27.3 \\
\hline $\mathrm{K}$ & 985 & 44.3 & $\mathrm{Zn} / \mathrm{Cd}$ & 500 & 750 to 1000 & 101,564 \\
\hline $\mathrm{Se}$ & 0.0594 & $2.67 \mathrm{e}-3$ & $\mathrm{Fe} / \mathrm{Co}$ & 440 & $-{ }^{\mathrm{a}}$ & 4,660 \\
\hline $\mathrm{Cd}$ & 0.0002 & $8.99 \mathrm{e}-6$ & $\mathrm{Na} / \mathrm{Mg}$ & 4.00 & 2 to 6 & 3.91 \\
\hline $\mathrm{Ni}$ & 0.0009 & $4.05 e-5$ & $\mathrm{~K} / \mathrm{Co}$ & 2000 & $-^{\mathrm{a}}$ & 532,642 \\
\hline $\mathrm{P}$ & 781 & 35.1 & $\begin{array}{l}\mathrm{K} /(\mathrm{Ca} \quad+ \\
\mathrm{Mg})\end{array}$ & 2.2 & $-{ }^{\mathrm{a}}$ & 17.7 \\
\hline $\mathrm{Co}$ & 0.0019 & $8.54 \mathrm{e}-5$ & $\mathrm{Na} / \mathrm{K}$ & 2.40 & 1.4 to 3.4 & $3.24 \mathrm{e}-1$ \\
\hline $\mathrm{Na}$ & 320 & 14.4 & ${ }^{\mathrm{b}}$ & $-{ }^{\mathrm{b}}$ & $-{ }^{b}$ & $-{ }^{b}$ \\
\hline Total & 2,225 & 100 & $-{ }^{b}$ & $-{ }^{\mathrm{b}}$ & $-{ }^{b}$ & $-{ }^{\mathrm{b}}$ \\
\hline
\end{tabular}

Potassium is primarily an intracellular cation, most part being bound to protein and with sodium influences osmotic pressure and contributes to the normal $\mathrm{pH}$ equilibrium [36]. Dietary lack of potassium is seldom found as both plants and animal tissues are rich sources of the mineral. In kilishi, $\mathrm{K}$ value was 985 $\mathrm{mg} / 100 \mathrm{~g}$ making a percentage of 44.3 of the total mineral analysed for. This showed that $\mathrm{K}$ was dominant quantitatively over other minerals like phosphorous, sodium and magnesium. Sodium regulates water content of the body, aids in transport of $\mathrm{CO}_{2}$ and maintains osmotic pressure of body fluids. Magnesium repairs and improves the growth of human body, maintains blood pressure, prevents tooth decay and helps to keep bones healthy. Zinc is a part of many enzymes, required for the body immune system, having role in cell division, growth and wound healing. Selenium prevents cancer, poisonous effect of heavy metals and helps the body after vaccination [2]. Iron is one of the key minerals present in meat, it plays a vital role in human health and its deficiency causes several hinderances in the normal functioning of human body, particularly disturbs child growth and development [37]. Iron is available in a number of food stuffs and occurs in two forms like heme and non-heme iron. The former one comes from the hemoglobin and myoglobin, so it is present in animal foods only and has a high degree of bioavailability that could easily be absorbed in the intestinal lumen [38].

The mineral ratios are often more important than the individual mineral levels themselves and this had been illustrated by the following statements by Vitale et al., as quoted by Watts [8]: "Determining nutritional interrelationships is much more important than knowing minerals levels alone. From a global standpoint, although dietary deficiency is at the more serious end of the spectrum, the opposite end, dietary 
excess and aberrations contribute to the burden of disease". "Mild and subclinical deficiencies of nutrients outnumber overt syndromes ten to one". In the present report under discussion, calculated significant ratio values were $\mathrm{Ca} / \mathrm{P}, \mathrm{Na} / \mathrm{K}, \mathrm{Ca} / \mathrm{K}, \mathrm{Ca} / \mathrm{Mg}, \mathrm{Zn} / \mathrm{Cu}$ and $\mathrm{Fe} / \mathrm{Cu}$. These mentioned mineral ratios revealed not only the important balance between these elements, but they also provide information regarding the many possible factors that may be represented by a disruption of their relationships, such as disease states, physiological and developmental factors, the effects of diet, drugs, would also predispose a person with parasympathetic dominance to certain health conditions if severe or chronic [8].

The $\mathrm{Na} / \mathrm{Mg}$ had the following information ideally there should be $4: 1$ ratio of sodium relative to magnesium with a range of 2 to 6 being acceptable. The sample result gave a ratio of 3.91:1 which was within the acceptable range of 2 to 6 . All these following significant ratios have their values in the results being less than the ideal and also not falling within acceptable ideal range: $\mathrm{Ca} / \mathrm{Mg}$ (3.62 e-1 to 1$), \mathrm{Ca} / \mathrm{K}(3.00 \mathrm{e}-2$ : 1 ), $\mathrm{Ca} / \mathrm{P}(3.78 \mathrm{e}-2: 1)$ and $\mathrm{Na} / \mathrm{K}(3.24 \mathrm{e}-1: 1)$. Toxic mineral ratios in this result were $\mathrm{Fe} / \mathrm{Pb}, \mathrm{Ca} / \mathrm{Pb}$ and $\mathrm{Zn} / \mathrm{Cd}$ whilst additional ratios were $\mathrm{Fe} / \mathrm{Co}$ and $\mathrm{K} / \mathrm{Co}$. It should be noted that $\mathrm{Zn} / \mathrm{Cu}$ and $[\mathrm{K} /(\mathrm{Ca}+\mathrm{Mg})]$ are good in nutritional discussion. Mineral ratios analyses have been very important in analysis of hair as a biochemical marker. The ratios mostly reported here were for the purpose of gathering analytical data.

The mineral safety index (MSI) values of kilishi were shown in Table 3. For easy verification of the calculation, the following information were provided: recommended adult intake (RAI), standard or table value (TV) of MSI and our calculated kilishi MSI values depicted as CV. The difference (D) between TV - CV values were shown to be high and positive for Fe, $\mathrm{Ca}, \mathrm{P}, \mathrm{Mg}, \mathrm{Cu}, \mathrm{Se}$ and $\mathrm{Na}$ with their percentage differences that ranged from 15.1 - 975, i.e. standard values were higher in those values than we calculated for kilishi within the range of $15.1-975 \%$. Whereas the least difference occurred in Se $(15.1 \%)$, Ca depicted the highest difference with a value of $975 \%$. Zinc was the odd mineral out as the TV $-\mathrm{CV}=-7.22$ and $\mathrm{TV}-$ CV/TV (\%) was -21.9. This meant the MSI Zn (standard) was lower than the calculated MSI for zinc. Since standards were not available for K, Mn, Co, and $\mathrm{Pb}$, their kilishi MSI were not calculated for.

In Table-3, the mineral safety index (MSI) of some minerals were depicted whose standard comparisons were available from literature. The table value (TV) MSI values were in column 3 of Table 3 . The explanation of the MSI calculation could be followed thus: taking $\mathrm{Ca}$ as an example: the recommended adult intake (RAI, column 2 Table 3 ) of $\mathrm{Ca}$ is $1200 \mathrm{mg}$, its minimum toxic dose (MTD) is $12000 \mathrm{mg}$ or 10 times the recommended daily average (RDA) which is equivalent to MSI of $\mathrm{Ca}$. This reasoning goes for the other minerals whose MSI were determined. Only zinc had its MSI in kilishi greater than the standard value $(40.2>33.0)$ thereby giving negative difference whilst others gave positive differences. The negative difference in Zn MSI was 7.22 and percentage difference of 21.9 [TV $\mathrm{CV} / \mathrm{TV} \%)]$. This meant that $\mathrm{Zn}$ might be overloading the consumer to the tune of $21.9 \%$. When the $\mathrm{MSI}_{\text {Calculated }}<\mathrm{MSI}_{\text {Table }}$, it means such mineral would not constitute mineral overload or become toxic to the sample consumers. Furhermore, the MSI value for $\mathrm{Cu}$ showed that $\mathrm{Cu}$ might not impair the metabolism of $\mathrm{Fe}$, $\mathrm{Zn}$ and $\mathrm{Mn}$.

Table-3: Mineral safety index (MSI) of Fe, Ca, P, Mg, Zn, Se and Na of kilishi (beef jerky meat)

\begin{tabular}{|l|l|l|l|l|l|}
\hline Mineral & \multirow{2}{*}{ RAI (mg) } & \multirow{2}{*}{ TV of MSI } & \multicolumn{3}{|c|}{ Kilishi (beef jerky meat) } \\
\cline { 4 - 6 } & & & $\begin{array}{l}\text { Calculated } \\
(\mathbf{C V}) \text { MSI }\end{array}$ & $\begin{array}{l}\text { TV }- \text { CV } \\
(\mathbf{D})\end{array}$ & TV - CV/TV (\%) \\
\hline $\mathrm{Fe}$ & 15 & 6.70 & 3.85 & 2.85 & 42.5 \\
\hline $\mathrm{Ca}$ & 1200 & 10.0 & 0.2467 & 9.75 & 975 \\
\hline $\mathrm{P}$ & 1200 & 10.0 & 0.6512 & 9.35 & 93.5 \\
\hline $\mathrm{Mg}$ & 400 & 15.0 & 3.06 & 11.9 & 79.6 \\
\hline $\mathrm{Zn}$ & 15 & 33.0 & 40.2 & -7.22 & -21.9 \\
\hline $\mathrm{Cu}$ & 3 & 33.0 & 3.47 & 29.5 & 95.5 \\
\hline $\mathrm{Se}$ & 0.07 & 14.0 & 11.9 & 2.12 & 15.1 \\
\hline $\mathrm{Na}$ & 500 & 4.80 & 3.07 & 1.73 & 36.1 \\
\hline
\end{tabular}

$\mathrm{CV}=$ calculated MSI; TV = Table MSI; D = difference; RAI = recommended adult intake. No MSI standard for K, Mn, $\mathrm{Co}$, and $\mathrm{Pb}$.

The vitamins analyzed for in kilishi were shown in Table-4. Vitamins of significance in the sample were: retinol (A), $\alpha$ - tocopherol (E), riboflavin $\left(\mathrm{B}_{2}\right)$, niacin $\left(\mathrm{B}_{3}\right)$, pantothenic acid $\left(\mathrm{B}_{5}\right)$, pyridoxamine $\left(\mathrm{B}_{6}\right)$ and ascorbic acid $(\mathrm{C})$. With a total vitamin content of $17.0 \mathrm{mg} / 100 \mathrm{~g}$, highest concentrated vitamin was vitamin C (38.4\%), this was followed by niacin
$(35.2 \%)$, third mostly concentrated was retinol $(11.4 \%)$ and fourth concentrated being $\alpha$ - tocopherol $(8.10 \%)$. The following vitamins were in traces: cholecalciferol $(6.23 \mathrm{e}-4 \%)$, phylloquinone $(2.00 \mathrm{e}-1 \%)$, thiamine $(2.14$ e-1\%), folic acid (6.29 e-2\%) and cyanocobalamin $(7.38 \mathrm{e}-3 \%)$. 
Vitamins are a group of organic substances that function in a variety of dimensions in human body. They are generally classified into two groups on the basis of their solubility in water and fat, i.e., water soluble vitamins and fat soluble vitamins. In this report, the water soluble vitamins determined were the Bcomplex vitamins (thiamine, riboflavin, niacin, pantothenic acid, pyridoxamine, folic acid, cyanocobalamin) and vitamin C. Fat soluble vitamins in this report were vitamin $\mathrm{A}, \mathrm{D}, \mathrm{K}$ and $\mathrm{E}$. The vitamin composition as determined in the sample can be seen in Table 4. Vitamins of significance in the samples were: in the water soluble vitamins - vitamin $\mathrm{C}$ was highest in both water soluble and fat soluble vitamins with a concentration of $6.53 \mathrm{mg} / 100 \mathrm{~g}(38.4 \%)$ and the second water soluble vitamin of significance was niacin with a value of $5.98 \mathrm{mg} / 100 \mathrm{~g}(35.2 \%)$; the two significant fat soluble vitamins were vitamin A, 1.94mg/100g (11.4\%) and vitamin E, $1.38 \mathrm{mg} / 100 \mathrm{~g}(8.10 \%)$. Vitamins greater than $0.10 \mathrm{mg} / 100 \mathrm{~g}$ which were water soluble were vitamins $\mathrm{B}_{2}, \quad 2.94 \mathrm{e}-1 \mathrm{mg} / 100 \mathrm{~g}(1.73 \%), \mathrm{B}_{5}, \quad 3.85 \mathrm{e}-$ $1 \mathrm{mg} / 100 \mathrm{~g}(2.65 \%)$ and $\mathrm{B}_{6}, 4.07 \mathrm{e}-1(2.39 \%)$. These vitamins were in trace levels: vitamins $\mathrm{D}$ and $\mathrm{K}$ (all fat soluble). In literature, vitamins of the following meat sources were reported (beef, bacon, mutton, veal and pork) $[39,40]$. Vitamins $A$ and $D$ were in traces in the meat sources mentioned earlier; $\mathrm{B}_{1}$ ranged from 0.06 $1.2 \mathrm{mg} / 100 \mathrm{~g} ; \mathrm{B}_{2}$ ranged from $0.16-0.26 \mathrm{mg} / 100 \mathrm{~g}$ (all lower than in kilishi); $B_{5}$ ranged from $0.4-0.6 \mathrm{mg} / 100 \mathrm{~g}$ (values close to that in kilishi); $\mathrm{B}_{9}$ ranged from nil -9 $\mu \mathrm{g}$ (lower than in kilishi $=10.7 \mu \mathrm{g}$ ); $\mathrm{B}_{6}$ ranged from 0.2 $-0.4 \mathrm{mg} / 100 \mathrm{~g}$ (lower than kilishi); $\mathrm{B}_{12}$ ranged from nil $2 \mu \mathrm{g}$ (closer to kilishi $=1.25 \mu \mathrm{g}$ ) and vitamin $\mathrm{C}$ from nil - nil (much lower than in kilishi $=6.53 \mathrm{mg} / 100 \mathrm{~g}$ ).

Table-4: The vitamin composition (mg/100g) of kilishi (beef jerky meat)

\begin{tabular}{|l|l|l|l|l|}
\hline Vitamin & Common name & CID & Content & \% content \\
\hline A: Fat soluble & & & & \\
\hline A & Retinol & 445354 & 1.94 & 11.4 \\
\hline $\mathrm{D}$ & Cholecalciferol & 5280795 & $1.06 \mathrm{e}-4$ & $6.23 \mathrm{e}-4$ \\
\hline $\mathrm{E}$ & $\alpha$-Tocopherol & 14985 & 1.38 & 8.10 \\
\hline $\mathrm{K}$ & Phylloquinone & 5280540 & $3.40 \mathrm{e}-2$ & $2.00 \mathrm{e}-1$ \\
\hline $\mathrm{B}:$ Water soluble & & & & \\
\hline $\mathrm{B}_{1}$ & Thiamine & 1130 & $3.64 \mathrm{e}-2$ & $2.14 \mathrm{e}-1$ \\
\hline $\mathrm{B}_{2}$ & Riboflavin & 493570 & $2.94 \mathrm{e}-1$ & 1.73 \\
\hline $\mathrm{B}_{3}$ & Niacin & 938 & 5.98 & 35.2 \\
\hline $\mathrm{B}_{5}$ & Pantothenic acid & 6613 & $3.85 \mathrm{e}-1$ & 2.65 \\
\hline $\mathrm{B}_{6}$ & Pyridoxamine & 1054 & $4.07 \mathrm{e}-1$ & 2.39 \\
\hline $\mathrm{B}_{9}$ & Folic acid & 6037 & $1.07 \mathrm{e}-2$ & $6.29 \mathrm{e}-2$ \\
\hline $\mathrm{B}_{12}$ & Cyanocobalamin & 5311498 & $1.25 \mathrm{e}-3$ & $7.38 \mathrm{e}-3$ \\
\hline $\mathrm{C}$ & Ascorbic acid & 54670067 & 6.53 & 38.4 \\
\hline Grand totals & - & - & 17.0 & 100 \\
\hline \multicolumn{5}{|l|}{$=$ not applicable; CID $=$ compound ID } \\
\hline
\end{tabular}

Vitamin A is necessary for the maintenance of healthy tissues for maintaining the normal vision and eyesight. Vitamin E comes under the group of tocopherols or tocotrienols. The RDA for male (1970years) is $15.0 \mathrm{mg}$ per day; this is much higher than the kilishi result [41]. It's deficiency is said to be very rare; sterility in males and abortions in females, mild hemolytic anemia in newborn infants. Tissue defence mechanism against free radical damage generally involve vitamin $\mathrm{C}$, vitamin $\mathrm{E}$ and $\mathrm{B}$-carotene as the major vitamin anti-oxidants in extracellular fluids [42]. Other fat soluble vitamins in kilishi were in traces: vitamin D (1.06e-4mg/100g, 6.23e-4\%) and vitamin $\mathrm{K}$ (3.40e-2mg/100g, 2.00e-1\%).

Vitamin $\quad \mathrm{B}_{1} \quad(3.64 \mathrm{e}-2 \mathrm{mg} / 100 \mathrm{~g}, \quad 2.14 \mathrm{e}-1 \%)$ works along with other B-complex vitamins to carry out numerous chemical reactions required for the growth and maintenance of the human body. It is involved in the metabolic processes necessary for energy production to perform various body functions. Deficiency of thiamine could cause loss of appetite, fatigue, constipation, irritability and depression [2]. Vitamin $B_{2}(2.94 \mathrm{e}-1 \mathrm{mg} / 100 \mathrm{~g}, 1.73 \%)$ is essential to release energy from the major food constituents like proteins, fats and carbohydrates. It helps in retaining good eye sight and healthy skin as well as aiding the absorption and utilization of iron. It is also required in the conversion process from tryptophan to niacin [2]. Vitamin $\mathrm{B}_{2}$ deficient person has the accumulation of fat in the liver which resembles changes observed in the liver of chronic alcoholics. In humans with liver cirrhosis, decreased concentration of vitamin $B_{2}$ is found mostly in necrotic regions [43]. The value of vitamin $\mathrm{B}_{2}$ in kilishi was low and would require supplementation with riboflavin-rich foods. Niacin (vitamin $\mathrm{B}_{3}$ ) was high in kilishi $(5.98 \mathrm{mg} / 100 \mathrm{~g}, 35.2 \%$ ). The term niacin has been used generally to encompass the active forms of this vitamin, nicotinic acid and nicotinamide; although estimates of niacin requirements take into account preformed niacin as well as that got as niacin equivalent in the body from tryptophan metabolism. Hence it was estimated that when $60 \mathrm{mg}$ of Trp is consumed by an adult, enough of Trp is oxidized 
to produce $1.0 \mathrm{mg}$ of niacin [44]. In 1980, RDA of niacin was 6.6 niacin equivalent (NE) per $1000 \mathrm{kcal}$ and intake not less than basic NE had been recommended when the calorie intake is less than $2000 \mathrm{kcal}$; one NE is equivalent to $1.0 \mathrm{mg}$ niacin (or 60mg Trp) [45]. The Trp level in kilishi (unpublished) was $1.02 \mathrm{~g} / 100 \mathrm{~g}$ $(1020 \mathrm{mg} / 100 \mathrm{~g})$. This meant that kilishi would be good source of vitamin $\mathrm{B}_{3}$ either directly or indirectly. The observed value of $5.98 \mathrm{mg} / 100 \mathrm{~g}$ in vitamin $\mathrm{B}_{3}$ almost doubled the values of $3.01 \mathrm{mg} / 100 \mathrm{~g}$ (male crab) and $3.18 \mathrm{mg} / 100 \mathrm{~g}$ (female crab) of $N$. maculatus [17]. Niacin deficiency causes the disease called pellagra which is characterized by the rough or raw skin. Other problems include memory loss, vomiting and diarrhea [2]. Vitamin $\mathrm{B}_{6}$ value was $4.07 \mathrm{e}-1 \mathrm{mg} / 100 \mathrm{~g}$ (2.39\%). Vitamin $\mathrm{B}_{6}$ is a generic name used for pyridoxine, pyridoxal and pyridoxamine, the co-enzyme forms of which are pyrodixal phosphate and pyridoxamine phosphate [45]. Vitamin $B_{6}$ is needed in the synthesis of DNA bases; it is a co-enzyme in the biosynthesis of thymedine, synthesis of neurotransmitters and important in the synthesis of heme iron, i.e., a component of hemoglobin. Also, it also helps in the synthesis of niacin from tryptophan. A dietary vitamin $\mathrm{B}_{6}$ deficiency or an increase in the thymedine requirement at a critical time during cell division could result in initial cell mutations that develop into tumor [46]. The RDAs were based on a ratio of $0.02 \mathrm{mg}$ of vitamin $\mathrm{B}_{6}$ per gramme of protein consumed. From this estimate, the vitamin $\mathrm{B}_{6}$ required to satisfy the protein composition (assuming as being main protein source) from the kilishi would be $0.02 \times 64.4=1.29 \mathrm{mg}$. The kilishi (4.07 e-1) value generally fell below the RDA standards. Vitamin $B_{5}$ had value of 3.85 e- $1 \mathrm{mg} / 100 \mathrm{~g}$ $(2.65 \%)$. People require vitamin $\mathrm{B}_{5}$ to synthesize and metabolize fats, proteins and co-enzyme A. Some functions of vitamin $\mathrm{B}_{5}$ include: converting food into glucose; synthesis of cholesterol; forming sex and stress-related hormones and forming red blood cells. The value of $3.85 \mathrm{e}-1 \mathrm{mg} / 100 \mathrm{~g}$ was higher than values of $0.18-0.81 \mathrm{mg} / 100 \mathrm{~g}$ observed in 10 fish species of Lakshadweep Sea [47]. Recommended daily intake ranged from $1.7 \mathrm{mg}$ per day to $7 \mathrm{mg}$ per day depending on the age status [48]; the present value was far from meeting this standard. Deficiency may lead to tiredness, depression, hypoglacaemia and increased sensitivity to insulin. Vitamin $\mathrm{B}_{9}$ was $1.07 \mathrm{e}-2 \mathrm{mg} / 100 \mathrm{~g}(6.29 \mathrm{e}-2 \%)$. Vitamin $\mathrm{B}_{9}$ (folate, folic acid, folacin) has a recommended adult daily intake in the U.S of $400 \mu \mathrm{g}$ from foods or direct supplements. Present kilishi report had a value of $1.07 \mathrm{e}-2 \mathrm{mg} / 100 \mathrm{~g}(10.7 \mu \mathrm{g} / 100 \mathrm{~g})$. Folic acid is essential for the body to make DNA, RNA, metabolise amino acids that are required for cell division. Not consuming enough folate can lead to folate deficiency that may result into a type of anaemia in which low numbers of large red blood cells occur. The value of $10.7 \mu \mathrm{g} / 100 \mathrm{~g}$ was close to the report of Lall and Parazo [49] who reported that the average folic acid content of fish and shellfish was $0.5-10 \mu \mathrm{g} / 100 \mathrm{~g}$ in flesh. Vitamin $B_{12}$ (cyanocobalamin) is found only in foods of animal origin; vegans (vegetarians who consume no animal products) are at risk for developing Cbl deficiency owing to suboptimal intake as vitamin $\mathrm{B}_{12}(\mathrm{Cbl})$ is essential for the synthesis of nucleic acids, erythrocytes and in the maintenance of myelin, deficiency may result in a variety of symptoms [50]. The daily human requirement is $1 \mu \mathrm{g}$. Value in kilishi was $1.25 \mathrm{e}-3 \mathrm{mg} / 100 \mathrm{~g}(7.83 \mathrm{e}-3 \%)(1.25 \mu \mathrm{g} / 100 \mathrm{~g})$ which slightly overshoot the standard by $0.25 \mathrm{e}-3 \mathrm{mg} / 100 \mathrm{~g}$. Vitamin $\mathrm{C}$ is active in the body either as ascorbic acid or as dehydro ascorbic acid. It plays important roles in many biochemical reactions including mixed-function oxidation involving incorporation of oxygen into the substrate [51]. The RDA of vitamin $\mathrm{C}$ for adults $(60 \mathrm{mg} /$ day) maintains a body pool of $1.5 \mathrm{~g}$ and $10 \mathrm{mg} /$ day is sufficient to prevent or cure scurvy [44]. The vitamin $\mathrm{C}$ kilishi value was low to the adult daily requirement to prevent or cure scurvy. Hence, supplements or fortification may be needed when kilishi serves as the main source of vitamin $\mathrm{C}$.

\section{CONCLUSION}

Kilishi is a snack with low fat because fat is removed during preparation and the fat that remained mostly dripped off during drying. Kilishi is packed full of protein; protein consumption boosts the body metabolism. One of the ingredients used in the preparation of kilishi is garlic, garlic is very good for the heart since the antioxidant properties of allicin (found in garlic) help lower cholesterol levels. Garlic in kilishi helps regulate blood pressure and blood sugar. Carbohydrates in kilishi was very low. Kilishi demonstrated to be sources of essential minerals and vitamins. The kilishi (as a meat product) is superior to beef probably due to its materials of production.

\section{REFERENCES}

1. Nigeria Today. (2016). Special Report, Nigeria's meat of possibilities (video documentary) Nigeria Today. 30 April, 2016.

2. Ahmad, R. S., Imran, A., \& Hussain M. B. (2018). Nutritional Composition of Meat. In Arshad, M. S. (Ed.). Meat Science and Nutrition, 61-77. BoD Books on Demand: Health and Fitness.

3. Umuoke, L. (2018). How to prepare kilishi. InfoGuideNIGERIA.COM (Information Guide in Nigeria), August 27, 2018.

4. Pearson, D. (1976). Chemical analysis of foods, 7th edition. London: J. and A. Churchill.

5. AOAC. (2006). Official Methods of Analysis. Maryland, USA: Association of Official Analytical Chemists, $18^{\text {th }}$ edition.

6. Varian, T. (1975). Basic Atomic Absorption Spectroscopy: a modern introduction. Springvale, Australia: Varian Techtron Pty Ltd.

7. Hatcock, J. N. (1985). Quantitative evaluation of vitamin safety. Pharmacy Times: 104-113.

8. Watts, D. L. (2010). HTMA mineral ratios: A brief discussion of their clinical importance. Trace Elements Newsletter, 21(1):1-3. 
9. Analytical Research Labs, Inc. (ARL) (2012). Basic ratios and their meaning. Arizona 85021, USA: Avenue - $\quad$ Phoenix http://www.alrtma.com/Articles/RatiosDoc

10. PubChem and the American Chemical Society. (2018). Reshaping Scholarly Communication. USA: University of California, $2005-05-31$. Retrieved 2018 - $10-15$.

11. Greenfield, H., \& Southgate, D. A. T. (2003). Food Composition Data, Production, Management and Use. Rome: FAO.

12. Adeyeye, E. I., Jegede, T., \& Mashood, Z. (2016). Proximate, mineral and mineral safety index of Acanthurus monroviae and Lutjanus goreensis fishes. Journal of Bio-Innovation. 5(1), 107-122.

13. WHO/FAO/UNU. (2007). Protein and amino acid requirements in human nutrition. Report of a Joint WHO/FAO/UNU Expert Consultation (WHO Technical Report Series 935). Geneva, Switzerland: World Health Organization.

14. Stamler, J., Elliott, P., Kesteloot, H., Nichols, R., Claeys, G. Dyer, A. R., \& Stamler, R. (1996). Inverse relation of dietary protein markers with blood pressure. Findings for 10020 men and women in the INTERSALT study. Circulation, 94:1629-1634

15. He, J., Klag, M. J., Whelton, P. K., Chen, J. Y., Qian, M. C., \& He, G. Q. (1995). Dietary macronutrients and blood pressure in southwestern China. Journal of hypertension,13(11), 12671274.

16. Millward, D. J. (1999). Optimal intakes of protein in the human diet. Proceedings of the Nutrition Society, 58: 403-413.

17. Adeyeye E. I., \& Jegede T. (2017). Chemical composition (proximate, minerals, vitamins), mineral ratios and mineral safety index of the innards of male and female Neopetrolisthes maculatus. Journal of Bio-Innovation. 6(3); 479 498.

18. Fornias, O.V. (1996). Edible by-products of slaughter animals. Rome, FAO: Animal Production and Health Paper 123.

19. Paul, A., \& Southgate, D. A. T. (1978). New food tables. Nutrition and Food Science, 78(1): 2-3.

20. Adeyeye, E. I., \& Adesina, A. J. (2014). Proximate, mineral compositions and mineral safety index of eight organs of guinea fowl (Numidia meleagris). Frontiers in Food Science and Technology. 1(1):7-13.

21. Bingham, S. (1978). Nutrition: a consumer's guide to good eating. London: Trans World Publishers.

22. Adeyeye, E. I., Oyarekua M. A., \& Adesina A. J. (2014). Proximate, mineral, amino acid composition and mineral safety index of Callinectes latmanus. International Journal of Development Research. 4(12), 2641-2649.

23. Adeyeye, E. I., \& Ayejuyo, O. O. (2007). Proximate, amino acid and mineral composition of turkey hen muscle and skin. Oriental Journal of Chemistry, 23(3), 879-886.

24. NACNE (National Advisory Committee on Nutrition Education). (1983). Proposal for nutritional guidelines for healthy education in Britain. London: Health Education Council.

25. Committee on Medical Aspects (COMA) of Food Policy. (1984). Diet and cardiovascular disease. London: HMSO.

26. Cowgwill, G. R. (1958). Evaluating body composition. Borden's Review of Nutrition Research, 19, 1-17.

27. Snively, W. D. Jr., \& Wessener, M. (1954). The ABC's of fluid balance. Journal of Indiana State Medical Association 47(9), 957-972.

28. White House Conferences. (1932). Growth and development of the child, III. Nutrition. New York: Appleton-Century-Crofts.

29. Pratt, E. L., \& Snyderman, S. E. (1953). Renal water requirement of infants fed evaporated milk with and without added carbohydrate. Pediatrics. 11(1):65-69.

30. Albanese, A. A. (Ed.) (1959). Protein and amino acid nutrition. New York and London: Academic Press.

31. FAO/WHO. (2001). Human vitamin and mineral requirements. Report of joint FAO/Who expert consultation, Bangkok, Thailand. FAO/WHO, Food and Nutrition Division. Rome: FAO.

32. Ghosh, A. K., \& Joshi, S. R. (2008). Disorders of calcium, phosphorous and magnesium metabolism. Journal of Association of Physicians, India, 56, 613-621.

33. Fleck, H. (1976). Introduction to nutrition, $3^{\text {rd }}$ Edn. New York: Macmillan.

34. Mertinez-Valverde, I., Periago, M. J., Santaella, M., \& Ros, G. (2000). The content and nutritional significance of minerals on fish flesh in the presence and absence of bone. Food Chemistry, 71, 503-509.

35. Tacon, A. G. J., \& Metian, M. (2013). Fish matters: importance of aquatic foods in human nutrition and global food supply. Reviews in Fishery Science, 21(1):22-38.

36. Sandstead, H. H. (1967). Present knowledge of minerals. In: Introduction to nutrition, 3rd edition edited by H. Fleck. New York: Macmillan, 522pp.

37. Lozoff, B., \& Georgieff, M. K. (2006). Iron deficiency and brain development. In Seminars in Pediatric Neurology 2006 Sep 1. Elsevier 13(3):158-165.

38. Simpson, R. J., \& Mckie, A. T. (2009). Regulation of intestinal iron absorption: The mucosa takes control? Cell Metabolism 10(2), 84-87.

39. McCance, R. A., \& Widdowson, E. M. (1960). The Composition of Foods $3^{\text {rd }}$ ed. London: Her Majesty's Stationary Office.

40. Williams, P. (2007). Nutritional composition of red meat. Nutrition and Dietetics 64(Suppl. 4), S113-S119. 
41. The National Academies. (2001). Dietary Reference Intakes: Vitamins. Washington DC: The National Academies Press.

42. Stocker, R., \& Frei, B. (1991). Endogenous antioxidant defences in human blood plasma. In: Oxidative stress: oxidants and antioxidants, Sies, H. (Editor). London, UK: Academic Press; 213243.

43. Chen, D. W., \& Zhang, M. (2006). Analysis of volatile compounds in Chinese mitten crab (Eriocheir sinensis). Journal of Food and Drug Analysis 14(3), 297-303.

44. NRC (National Research Council). (1980). Recommended dietary allowances, $9^{\text {th }}$ edition. Report of the Sciences: Assembly of Life Sciences. Washington DC: National Academy Press.

45. NRC (National Research Council). (1989). Recommended Dietary Allowances $10^{\text {th }}$ edition. Washington DC: National Academy Press.
46. Prior, F. G. (1985). Theoretical involvement of vitamin $\mathrm{B}_{6}$ in tumor initiation. Medical Hypotheses, 16, 421-428.

47. Dhaneesh, K.V., Noushad, K. M., \& Ajith, T. T. (2012). Nutritional evaluation of commercially important fish species of Lakshadweep Archipelago, India. PLoS ONE, 7(9), 1-7.

48. Christian, N. (2017). Vitamin $B_{5}$ : Everything you need to know. www.medicalnewstoday.com, Retrieved $5-82018$

49. Lall, S. P., \& Parazo, M. P. (1995). Vitamins in fish and shell fish. In: Ruither, A. (Edn.), Fish and Fishery products: composition, nutritive properties and stability. UK, pp: $157-186$.

50. Pawlak, R. I., Lester, S. E. I., \& Babatunde, T. I. (2004). The prevalence of cobalamin deficiency among vegetarians assessed by serum vitamin $B_{12}$ : a review of literature. European Journal of Clinical Nutrition, 68(5), 541-548.

51. Lee, R. M. (2000). Vitamin in animal and human health, $2^{\text {nd }}$ Edn. 2121 Southern State Avenue, Anes, Iowa 50014: Iowa State University Press. 